\title{
Efficacy of Sustained Acoustic Medicine as an Add- on to Traditional Therapy in Treating Sport-related Injuries : Case Reports
}

\author{
David 0 Draper $^{1 *}$, Aaron Wells ${ }^{1}$ and Kevin Wilk ${ }^{2}$ \\ ${ }^{1}$ Brigham Young University, USA \\ ${ }^{2}$ Champion Sports Medicine, USA
}

*Corresponding author: David 0. Draper, 106 SFH, Brigham Young University Provo, UT 84602, USA.

Received Date: August 26, 2020

Published Date: September 21, 2020

\begin{abstract}
Context: Musculoskeletal injuries are prevalent in sports, and the application of Sustain Acoustic Medicine (SAM) as a home-use add-on therapy to reduce pain and to increase the probability of athletes returning to sports was evaluated in a case series.

Objectives: To examine the improvements in pain and return to function of athletes using SAM in conjunction with traditional therapies after sustaining sports-related musculoskeletal injuries.

Introduction: Traditional treatments such as rest, physical therapy, manual therapy, a combination of rest, ice compression, and elevation (RICE) are standard of care for musculoskeletal injuries and do not provide adequate accelerated healing to return athletes to activity. SAM is an FDA-approved bio-regenerative technology, which can provide mechanotransductive and thermal stimuli to accelerate tissue healing and reduction in pain daily. Interventions: A case series of 18 athletes who showed little or no improvement with traditional therapies where prescribed SAM treatment as an add-on daily home-use intervention. The study included athletes with sports musculoskeletal injuries, including the arm/shoulder, upper leg/glutes/hips, knees, back, and foot/ankle. Clinical outcomes were recorded along with the ability of athletes' ability to go back to sports, and satisfaction and usability measures of the home treatment. Results: All athletes were satisfied with the usability and comfort of the therapy and 93\%reported the therapy was sufficiently discrete. Clinical outcomes indicate all athletes showed an average pain decrease of $3.33 \pm 0.82$ ( $p \leq 0.05$ ) numerical rating scales (NRS), improvement in function, and quality of life. 87\% of the athletes documented an improvement in function, and 55\% were able to return to sports after conservative intervention failed. Conclusion: The results of this study indicate that SAM improves athletes' clinical outcomes. Over $50 \%$ of athletes were able to return to sports and resume normal daily function after conservative intervention had failed with addition of daily SAM treatment.
\end{abstract}

Keywords: Low-Intensity Ultrasound; Continuous Ultrasound; Long-Duration Ultrasound; Athletic Training; Clinical Trial, Musculoskeletal Injury, Musculoskeletal Healing, Acute Pain; Chronic Pain

Abbreviations: RICE: Rest, Ice, compression, and Elevation; NSAIDs: Non-Steroidal Anti-Inflammatory Drugs; LICUS: Low-intensity continuous ultrasound; SAM: Sustained Acoustic Medicine; ACL: Anterior Cruciate Ligament; NRS: Numerical Rating Scale; WOMAC: Western Ontario McMaster Osteoarthritis Index

\section{Introduction}

Musculoskeletal injuries are the most common injuries in recreational, amateur, and professional sports [1-4]. Approximately
$64 \%$ of injuries in recreational sports are musculoskeletal related injuries [5]. Approximately 2 million injuries, 500,000 doctor visits, 
and 30,000 hepatization in high school students are associated with sports injuries [5,6]. The National Institute of Arthritis and Musculoskeletal and Skin Diseases has reported that 2.6 million children under 19 years old get treated for musculoskeletal injuries in emergency departments [7]. Hootman et al. reported that more than $50 \%$ of sports injuries in college students are in lower extremities with additional injuries reported in upper extremities and back/neck [8]. Historical data of American college football players show an increased number of upper shoulder and arm surgeries. Professional sports data is relatively discreet. Ekstrand et al. has reported that average soccer players sustained 2 injuries per season, leading to missing 37 days in a season $[1,9]$. Furthermore, 92\% of all muscle injuries are associated with lower limb: hamstring (37\%), adductors (23\%), quadriceps (19\%), and calf muscles (13\%)[10]. A recent study by Humprey et al. reported professional tennis players to sustain most of their injuries at muscles (24\%), tendon (23.4\%), and soft tissue bruising (6.5\%)[3]. Detailed studies have shown that the overuse of musculoskeletal anatomy further adds to injuries and probabilities of the future of reinjuries [1].

The musculoskeletal healing process involves activation of the cascade of cellular and molecular pathways $[11,12]$. The initial response to the injury is the activation of inflammatory cytokines. Acute inflammation is an essential part of the healing process, but chronic inflammation leads to the delayed healing process as well as further damage to the tissue; thus, it is necessary to remove inflammatory cytokines and initiate the regeneration of new tissue. Currently, to restrain the level of inflammation and enhance tissue healing, athletic trainers most commonly use rest, ice compression, and elevation (RICE) method. RICE reduces the inflow of the inflammatory factors, along with reducing the blood flow to the injury site $[13,14]$. RICE has limited efficacy in reducing inflammation and improving the rate of tissue regeneration over the healing process. Still, there is a need for add-on therapies to expedite the healing process and tissue regeneration [15-18].

Post-injury, the most important concern for an athlete is when to "return to play"? [19] This is a hard question to answer considering the multifactorial factors such as the site of injury, damage sustained, athletes' age, and the number of revised injuries along with other potential health concerns $[19,20]$. Doctors and athletic trainers are advised to have a conservative approach, but at the same time, it important to minimize the athlete's off-field time. Thus, it is important to come with more advance, innovative, and non-invasive therapies to accelerate tissue healing.

Ultrasound therapy provides a mechanotransducive localized stimulus to the injury site resulting in increased blood flow, oxygenation, exchange of nutrition, and accelerated tissue healing resulting in inhibition of inflammation [21-25]. Multiple studies have shown tissue regenerative properties of ultrasound. Ultrasound increases the rate of bone healing by decreasing initial infiltration of cytokines increasing, angiogenesis, chondrogenesis, and bone remodeling [22,23,26,27]. Studies have concluded the application of ultrasound increases the rate of tendon-bone interface healing in preclinical models [28-31]. Walsh et al. has shown similar trends in anterior cruciate ligament reconstruction [31].

Ultrasound is a non-invasive therapy with significant data supporting its regenerative efficacy in preclinical studies [21,28,3234]. The effectiveness of ultrasound is dependent on multiple factors such as duty cycle, intensity, duration, frequency, and energy [21,3537]. While ultrasound therapy has been around for a long time, its transformation to clinical practice has been limited due to the optimization of ultrasound parameters. Low-intensity continuous ultrasound (LICUS) has shown the potential to accelerate the tissue regeneration process significantly. Sustained Acoustic Medicine (SAM) uses LICUS to expedite the healing process and have shown encouraging results in clinical studies [28,38-43]. SAM $®$ has been approved for pain management by Food and Drug Management (FDA). Langer et al., in a clinical study $(n=30)$ has shown that after use application of SAM (3MHz, 0.132W/cm2, 18720 Joules) for 4 hours reduced pain by $15 \%$ compared to $7 \%$ in the placebo group in Trapezium muscle spasm. They also showed 52\% $(\mathrm{p}<0.05)$ improvement in the visual analog score (VAS) in rotator cuff pain, $40 \%(\mathrm{p}<0.03)$ pain reduction in osteoarthrosis patients $(\mathrm{N}=47)$, and 4.28 point VAS $(\mathrm{p}<0.001)$ decrease in tendon pain relief and recovery $(\mathrm{N}=25)$ after 6 weeks of treatment $[41,42]$. Lewis et al. has reported an up to 1point increase in Global Rating of Change (GROC) score and a $25 \%$ reduction in VAS reduction after 10 days of SAM treatment in chronic myofascial pain [43]. The objective of this study is to evaluate the effects of SAM in sports-related injuries as an adjuvant therapy to athletes when conservative treatment fails.

\section{Materials and Methods}

\section{Participants}

Participants $(\mathrm{N}=18)$ included amateur and professional athletes from different sports who did not respond to traditional musculoskeletal therapies with an average age of $30 \pm 13.31$ (13 Males, 5 Female) Table 1. Participate were screened before the study and excluded from the study if they 1) had surgeries, 2) used opioid-based medication, 3) any implants, 4) Intramuscular or articular steroid injections, and 5) using systemic/oral nonsteroidal anti-inflammatory drugs (NSAIDs). The participants were included if they 1) using adjunctive therapy, 2) sports-related injury, and 3) cognitively able to follow the instruction to use the medical device. The participants included athletes with arm injuries $(n=3)$, shoulder $(n=1)$, neuropathy $(n=1)$, back $(n=3)$, ribs $(n=1)$ upper leg $(n=5)$, knee $(n=3)$, and foo/ankle $(n=1)$ Figure 1 . The participants signed the consent form, and observations were conducted per declaration for Helsinki [44] (Table 1) (Figure 1).

\section{SAM Device}

The LICUS was delivered using an FDA approved SAM $®$ (ZetrOZ Systems LLC, Trumbull, CT) (Figure 2). The device consists of two 
transducers that deliver ultrasound at $3 \mathrm{MHz}, 0.132 \mathrm{~W} / \mathrm{cm} 2,1.3 \mathrm{~W}$, Athletes were trained to use how to use the device properly with an each delivering total of 18720 Joules over 4 hours of treatment. ultrasound gel adhesive patch by trained medical staff (Figure 2,3).

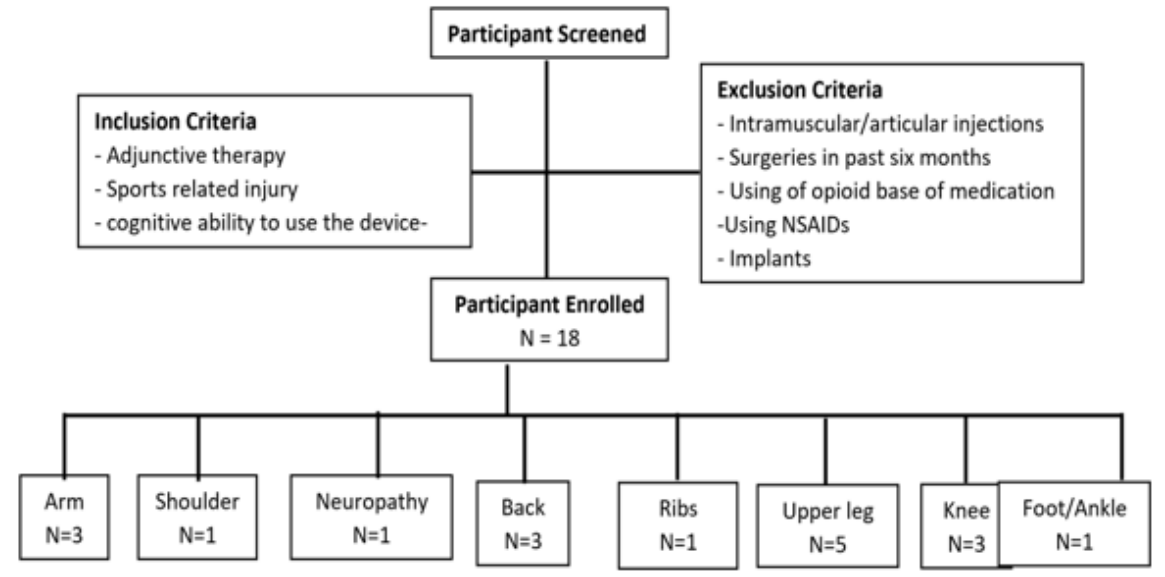

Figure 1: Participant criteria and sites of musculoskeletal injury treated.

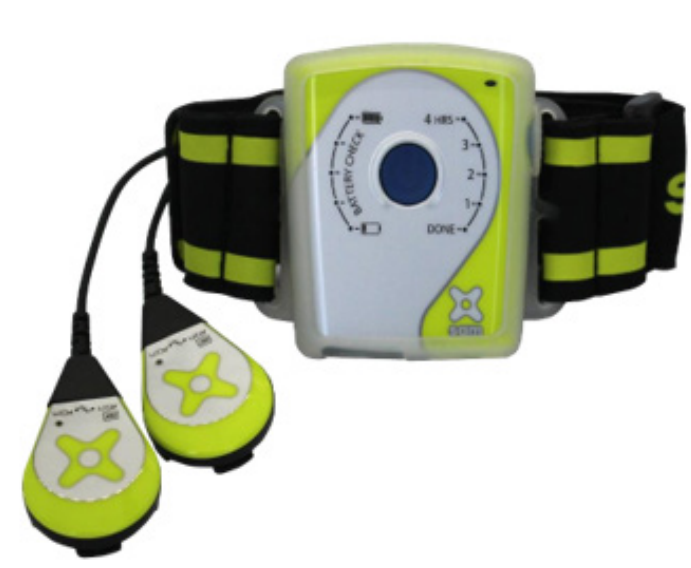

Figure 2: The SAM® device Two transducers (Crystals) and one power controller in an arm strap. Two transducers deliver ultrasound at $3 \mathrm{MHz}, 0.132 \mathrm{~W} / \mathrm{cm} 2,1.3 \mathrm{~W}$, each delivering total of 18720 Joules over 4 hours of treatment.

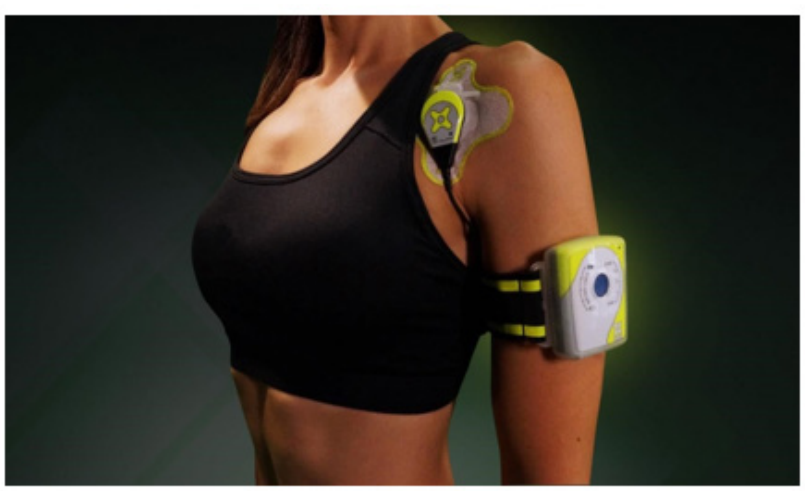

Figure 3: Application of $S A M \circledast$ to the shoulder.

Table 1: Athlete cohort and demographics.

\begin{tabular}{|c|c|c|c|c|}
\hline Location & Diagnosis & Age & Gender & Sport \\
\hline Arm & Left epicondylosis & 38 & M & Gym/exercise \\
\hline Arm & Olecronon bursitis & 32 & M & Gym/exercise \\
\hline
\end{tabular}




\begin{tabular}{|c|c|c|c|c|}
\hline Arm & Radial contusion & 17 & F & Softball \\
\hline Shoulder & Chronic supraspinatus tendinosis, impingement & 32 & M & Baseball \\
\hline Neuropathy & Left-arm neuropathy & 35 & M & Unknown \\
\hline Back & Lumbar disc herniation & 20 & F & Crew \\
\hline Back & Lumbar disc herniation & 54 & Golf & Basketball \\
\hline Back & Low back pain & 45 & M & Hockey \\
\hline Ribs & $12^{\text {th }}$ rib bone bruise & 18 & Soccer \\
\hline Upper Leg & Right hip piriformis syndrome & 16 & M & Baseball \\
\hline Upper Leg & Hip flexor/quadriceps strain & 15 & F & Soccer \\
\hline Upper Leg & Right hamstring strain & 32 & M & Baseball \\
\hline Upper Leg & Hamstring tear & 60 & F & Gym/exercise \\
\hline Upper Leg & Gluteus medius tendinopathy & 37 & M & Running \\
\hline Knee & Patellar tendinosis & 17 & F & Basketball \\
\hline Knee & Right knee; ACL tear & 24 & M & Football \\
\hline Knee & Osteochondral fracture & 19 & M & Lacrosse \\
\hline Foot/Ankle & Distal posterior tibial tendinopathy & &
\end{tabular}

Table 2: Device Use.

\begin{tabular}{|c|c|c|}
\hline Device Use & Yes & No \\
\hline Was the device easy to use? Would you describe sam as "userfriendly"? & 18 & 0 \\
\hline Is the device sufficiently discrete? & 17 & 1 \\
\hline Is the device comfortable to wear while going about daily activities? & 18 & 0 \\
\hline Did the patient experience any skin sensitivity? & 2 & 16 \\
\hline
\end{tabular}

Table 3: Clinical Outcomes demonstrating changes in pain, functionality and return to sports post LIPUS addon treatment.

\begin{tabular}{|c|c|c|c|c|c|c|c|c|c|}
\hline $\begin{array}{l}\text { Loca- } \\
\text { tion }\end{array}$ & $\begin{array}{l}\text { Diagno- } \\
\text { sis }\end{array}$ & $\begin{array}{c}\text { Treatments } \\
\text { Per Week }\end{array}$ & $\begin{array}{l}\text { Pre-Sam } \\
\text { Treatment }\end{array}$ & Effects & $\begin{array}{l}\text { Additive Treat- } \\
\text { ment + Sam }\end{array}$ & $\begin{array}{l}\text { Treatment } \\
\text { Timeline } \\
\text { (Weeks) }\end{array}$ & $\begin{array}{c}\text { Pain Reduc- } \\
\text { tion }\end{array}$ & $\begin{array}{l}\text { Increased ROM/ } \\
\text { Function }\end{array}$ & $\begin{array}{l}\text { Returned To } \\
\text { Work/Sports }\end{array}$ \\
\hline Arm & $\begin{array}{l}\text { Left } \\
\text { epicondy- } \\
\text { losis }\end{array}$ & 7 & Ice. Rest. & $\begin{array}{l}\text { Minimal } \\
\text { Change }\end{array}$ & Ice. Rest. & 1 & Yes & Yes & Yes \\
\hline Arm & $\begin{array}{l}\text { Olecronon } \\
\text { bursitis }\end{array}$ & 7 & $\begin{array}{l}\text { Typical PT, } \\
\text { stretching }\end{array}$ & No Change & $\begin{array}{l}\text { manual therapy, } \\
\text { therapy educa- } \\
\text { tion }\end{array}$ & 2 & Yes & Yes & No \\
\hline Arm & $\begin{array}{l}\text { Radial } \\
\text { contusion }\end{array}$ & 7 & Ice & No change & $\begin{array}{c}\text { manual therapy, } \\
\begin{array}{c}\text { therapy educa- } \\
\text { tion }\end{array} \\
\end{array}$ & 1 & Yes & Yes & Yes \\
\hline $\begin{array}{c}\text { Shoul- } \\
\text { der }\end{array}$ & $\begin{array}{l}\text { Chronic } \\
\text { supraspi- } \\
\text { natus ten- } \\
\text { dinosis, } \\
\text { impinge- } \\
\text { ment }\end{array}$ & 7 & $\begin{array}{c}\text { Heat, } \\
\text { Ice, rest, } \\
\text { stretching, } \\
\text { electrical } \\
\text { stimula- } \\
\text { tion, manu- } \\
\text { al therapy }\end{array}$ & No change & $\begin{array}{l}\text { Muscle therapy, } \\
\text { muscle activa- } \\
\text { tion }\end{array}$ & 2 & Yes & Yes & Yes \\
\hline $\begin{array}{l}\text { Neurop- } \\
\text { athy }\end{array}$ & $\begin{array}{l}\text { Left-arm } \\
\text { neuropa- } \\
\text { thy }\end{array}$ & 7 & $\begin{array}{l}\text { Typical PT, } \\
\text { stretching }\end{array}$ & No Change & \begin{tabular}{|c|}
$\begin{array}{c}\text { manual therapy, } \\
\text { therapy educa- } \\
\text { tion }\end{array}$ \\
\end{tabular} & 2 & Yes & Yes & Yes \\
\hline Back & $\begin{array}{l}\text { Lumbar } \\
\text { disc her- } \\
\text { niation }\end{array}$ & 5 & $\begin{array}{l}\text { Typical PT, } \\
\text { stretching }\end{array}$ & No Change & $\begin{array}{l}\text { manual therapy, } \\
\text { therapy educa- } \\
\text { tion }\end{array}$ & 1 & Yes & Yes & No \\
\hline Back & $\begin{array}{l}\text { Lumbar } \\
\text { disc her- } \\
\text { niation }\end{array}$ & 6 & $\begin{array}{l}\text { Strength, } \\
\text { ROM, Mas- } \\
\text { sage }\end{array}$ & No Change & $\begin{array}{l}\text { Manual Ther- } \\
\text { apy, Muscle } \\
\text { Activation }\end{array}$ & 1 & Yes & Not Significant & No \\
\hline Back & $\begin{array}{l}\text { Low back } \\
\text { pain }\end{array}$ & 5 & $\begin{array}{l}\text { Typical PT, } \\
\text { stretching }\end{array}$ & No Change & $\begin{array}{l}\text { manual therapy, } \\
\text { therapy educa- } \\
\text { tion }\end{array}$ & 2 & Yes & Not Significant & No \\
\hline
\end{tabular}




\begin{tabular}{|c|c|c|c|c|c|c|c|c|c|}
\hline Ribs & $\begin{array}{l}\text { 12th rib } \\
\text { bone } \\
\text { bruise }\end{array}$ & 4 & $\begin{array}{l}\text { Manual } \\
\text { therapy, } \\
\text { heat, } \\
\text { nutritional } \\
\text { changes }\end{array}$ & $\begin{array}{l}\text { Minimal } \\
\text { Change }\end{array}$ & $\begin{array}{c}\text { Physical ther- } \\
\text { apy }\end{array}$ & 1 & Yes & Yes & Yes \\
\hline $\begin{array}{l}\text { Upper } \\
\text { Leg }\end{array}$ & $\begin{array}{l}\text { Right hip } \\
\text { piriformis } \\
\text { syndrome }\end{array}$ & 5 & Ice, Heat & No Change & $\begin{array}{l}\text { Muscle therapy, } \\
\text { heat }\end{array}$ & 3 & Yes & Yes & No \\
\hline $\begin{array}{l}\text { Upper } \\
\text { Leg }\end{array}$ & $\begin{array}{l}\text { Hip flex- } \\
\text { or/quad- } \\
\text { riceps } \\
\text { strain }\end{array}$ & 7 & None & None & $\begin{array}{l}\text { manual therapy, } \\
\text { therapy educa- } \\
\text { tion }\end{array}$ & 2 & Yes & Yes & Yes \\
\hline $\begin{array}{l}\text { Upper } \\
\text { Leg }\end{array}$ & $\begin{array}{l}\text { Gluteus } \\
\text { medius } \\
\text { tendinop- } \\
\text { athy }\end{array}$ & 7 & $\begin{array}{l}\text { Surgery. } \\
\text { RICE. ACL } \\
\text { rehab }\end{array}$ & No Change & $\begin{array}{l}\text { Ice. Soft tissue } \\
\text { mobilization. } \\
\text { ACL rehab }\end{array}$ & 1 & Yes & Yes & Yes \\
\hline $\begin{array}{l}\text { Upper } \\
\text { Leg }\end{array}$ & $\begin{array}{c}\text { Right } \\
\text { hamstring } \\
\text { strain }\end{array}$ & 7 & $\begin{array}{l}\text { Manual } \\
\text { therapy, } \\
\text { Muscle } \\
\text { activation, } \\
\text { Ice }\end{array}$ & $\begin{array}{l}\text { Minimal } \\
\text { Change }\end{array}$ & $\begin{array}{l}\text { Manual Ther- } \\
\text { apy, Muscle } \\
\text { activation, Ice }\end{array}$ & 8 & Yes & Yes & Yes \\
\hline $\begin{array}{l}\text { Upper } \\
\text { Leg }\end{array}$ & $\begin{array}{l}\text { Ham- } \\
\text { string } \\
\text { tear }\end{array}$ & 3 & $\begin{array}{l}\text { Rest, ice, } \\
\text { compres- } \\
\text { sion }\end{array}$ & No change & $\begin{array}{l}\text { manual therapy, } \\
\text { therapy educa- } \\
\text { tion }\end{array}$ & 1 & Yes & Yes & No \\
\hline Knee & $\begin{array}{l}\text { Patellar } \\
\text { tendinosis }\end{array}$ & 7 & $\begin{array}{l}\text { Manual } \\
\text { therapy, } \\
\text { ice, muscle } \\
\text { activation }\end{array}$ & $\begin{array}{l}\text { Minimal } \\
\text { Change }\end{array}$ & $\begin{array}{l}\text { Manual therapy, } \\
\text { muscle activa- } \\
\text { tion }\end{array}$ & 4 & Yes & Yes & Yes \\
\hline Knee & $\begin{array}{l}\text { Right } \\
\text { knee; ACL } \\
\text { tear }\end{array}$ & 7 & $\begin{array}{l}\text { Manual } \\
\text { therapy, } \\
\text { Heat pack, } \\
\text { nutrition } \\
\text { changes }\end{array}$ & $\begin{array}{l}\text { Minimal } \\
\text { Change }\end{array}$ & Manual therapy & 2 & Yes & Yes & Yes \\
\hline Knee & $\begin{array}{l}\text { Osteo- } \\
\text { chondral } \\
\text { fracture }\end{array}$ & 7 & $\begin{array}{l}\text { MicroFrac- } \\
\text { ture Sur- } \\
\text { gery/RICE/ } \\
\text { Soft Tissue } \\
\text { mobiliza- } \\
\text { tion/Neu- } \\
\text { romuscular } \\
\text { Reeduca- } \\
\text { tion }\end{array}$ & $\begin{array}{l}\text { Minimal } \\
\text { Change }\end{array}$ & $\begin{array}{l}\text { Ice. Soft tissue } \\
\text { mobilization. } \\
\text { ACL rehab }\end{array}$ & 7 & Yes & Yes & Yes \\
\hline $\begin{array}{l}\text { Foot/ } \\
\text { Ankle }\end{array}$ & $\begin{array}{l}\text { Distal } \\
\text { posterior } \\
\text { tibial } \\
\text { tendinop- } \\
\text { athy }\end{array}$ & 4 & Ice. Rest. & No Change & $\begin{array}{l}\text { Ice. Soft tissue } \\
\text { mobilization. } \\
\text { Therapeutic } \\
\text { Exercise }\end{array}$ & - & Yes & Yes & No \\
\hline
\end{tabular}

\section{Result}

\section{Device use and utility}

17 out of 18 athletes found SAM $®$ user friendly, one athlete reported olecranon bursitis. Two athletes reported minor skin irritation due to the adhesives used (Table 2).

\section{Clinical outcomes}

The objective of this report was to examine the clinical change in pain associated with injury after treatment with $\mathrm{SAM} \otimes$ and return to regular functional activity or sports after the failure of conservative therapy (Table 3). All athletes (100\%) stated they had a benefit from using the device and had an improvement in pain with the average reported a decrease of $3.33 \pm 0.82(p \leq 0.05)$ numerical rate scale (NRS) on the scale of $1-10$ for 6 patients who reported pain score. All other patients reported the effectiveness of SAM $®$ treatment. Sixteen (16) out of 18 athletes (89\%) indicated an improvement in range of motion, and 10 out of 18 (55\%) reported to return to sporting activities after approximately 2.25 weeks of intervention. Case Results by Injury Site

\section{Arm}

Elbow1: Two patients were treated with $\mathrm{SAM} \AA$ for elbow injuries. The first athlete was a 38-year old male athlete with chronic left epicondylitis with pain worsened during movement and gripping. Traditional physical therapy and stretching were 
unsuccessful in rehabilitation. The addition of SAM ${ }^{\circledR}$ for 4 hours per day for 1 week resulted in significant relief of pain and resulting in a return to sporting activities.

Elbow2: The second athlete was a 32-year old male with olecranon (elbow) bursitis associated with physical exercise lasting 2 weeks. Minimal change in symptoms were reported with ice and rest. The addition of SAM ${ }^{\circledR}$ to his treatment regimen for 4 hours /day, for 2 weeks resulted in a reduction in pain severity. This athlete had an overall improvement in symptoms that allowed him to "perform activities of daily living and work activities with reduced pain." Radius. A 17-year old female softball pitcher with an acute injury was treated with $\mathrm{SAM} \otimes$; she had a contusion of her left radius (non-throwing arm) due to direct impact, resulting in sharp, localized pain that was further aggravated by continuing to pitch. The icing alone was inadequate to relieve pain. She was treated with soft tissue mobilization and SAM® ( 4 hours daily for 1 week), leading to an overall improvement in pain and enabling her to return to softball.

\section{Shoulder}

A 32-year old male professional baseball pitcher with chronic (2 years) supraspinatus tendinosis and impingement syndrome were treated with heat, ice, rest, stretching, electrical stimulation, and manual therapy for 2 years. The addition of SAM® ( 4 hours/ day) for 3 days per week for 1 week, along with muscle therapy, increased range-of-motion, and reduced pain (Figure 2).

\section{Neuropathy}

A 35-year old male reported sharp pain with numbness/ tingling in his left arm that radiated to his hand. The neuropathic pain was present in rest and at gripping motion and daily function. Prior treatment with typical physical therapy and stretching, as well as therapeutic ultrasound, were unsuccessful at relieving pain. This patient was treated with SAM ${ }^{\circ}$ for 4 hours/day for 2 weeks, along with manual therapy, therapeutic exercise, resulting in a significant decrease in pain. He displayed an increased range of motion, decreased tissue density, and increased strength and gripping while a reduction in tingling and numbness.

\section{Back}

Herniated Disc 1: A 20-year old female amateur rower with a lumbar disc herniation, reported sharp and radiating pain, with numbness and tingling lasting 2-3 weeks at the time. This athlete was treated with $\mathrm{SAM} \circledast$ for 4 hours/day for 2 weeks, in combination with manual therapy, and therapeutic exercise. The athlete reported relief of pain and an increased range of motion. She was able to attain "pain-free daily function, and to resume running and working out."

Herniated Disc 2: A 54-year old male professional golfer with 46 years in the sport who had a lumbar disc herniation. He had temporary pain relief with manual therapy, ice, and muscle activation sufficient to participate in sport, but symptoms inevitably returned within approximately 2 weeks. The SAM® was added (4 hours/day, 5 days per week) into his treatment regimen, along with manual therapy and muscle activation for 2 weeks. The athlete reported, $\mathrm{SAM} 囚$ as a valuable treatment alternative for times when muscle activation therapy was not available.

Herniated Disc 3: A 45-year old male amateur basketball player with chronic low back pain that worsened with play (during and after basketball). Manual therapy combined with using SAM $®$ 4 hours/day, 5 days/week for 2 weeks resulted in marked pain relief; specifically, he improved from having constant pain during exercise to having no pain during and after playing basketball with combined treatment. As a result of the decrease in pain, the athlete was able to have longer endurance on the court leading to improved overall function and improved active field time.

\section{Ribs}

An 18-year old male amateur hockey forward was treated for a bruise to the 12th rib. No pain was reported at rest, but sharp pain was reported at the movement. X-rays were negative for fracture. Initial therapy with manual therapy, heat, and nutritional changes yielded minor positive changes. However, when SAM $®$ was added (4 hours/day, 4 days over 1 week), the combined therapy changed the quality of his pain from "sharp" to "dull" and activity from moderate to mild.

\section{Upper Leg}

Piriformis. 16-year old male soccer goalkeeper with chronic (>1 year) piriformis syndrome affected his right hip. Traditional physical therapy, including stretching and use of therapeutic ultrasound, was unsuccessful at alleviating his symptoms. The combination of manual therapy, therapeutic exercises, education, in conjunction with the SAM®, used for 4 hours/day for 2 weeks, resulting in pain relief, reduction in strained tissue, and a return to functional goalie activities.

Hip Flexor/Quadriceps Strain. A 30-year old male professional baseball player (shortstop) with 20 years of experience in the sport. He had a hip flexor/quadriceps strain with sharp pain on extension. Conservative therapy with ice and heat yielded negligible improvement in symptoms. After 2 weeks of symptoms, the addition of SAM $\AA$ therapy for 4 hours/day, 5 days over 1 week, resulted in a reduction of pain and increased range-of-motion with extension.

Hamstring 1: A 15-year old female amateur soccer midfielder with more than 5 years in the sport. She suffered right hamstring strain with chronic symptoms ( $>1$ year) resulting from an apparent biomechanical imbalance. She reported sharp pain in the hamstring, particularly with running. Conservative physical therapy had been unsuccessful. Manual therapy, therapeutic exercises, and education were combined with daily SAM treatment (4 hours/day) for 1 week. The athlete then continued to use SAM® sporadically for 
over 2 months. The combined treatment protocol led to significant pain relief, allowing her to increase her speed and to resume soccer activities.

Hamstring 2: A 32-year old male professional baseball player (2nd baseman) with 22 years in the sport. He was treated for a hamstring tear (biceps femoris) with minimal benefit perceived from strength, range-ofmotion, and massage therapy. A 3-week treatment with SAM® (4 hours/day, 5 days/week) together with manual therapy and muscle activation resulted in pain relief and contusion reduction and a change in the quality of the residual pain from "sharp" to "dull.". This athlete reported that he "could feel an immediate impact of treatment" during and after the treatment sessions by the heating of the tissue and the increased range of motion (Figure 3).

Tendinopathy. A 60-year old female with chronic gluteus medius tendinopathy associated with physical exercise. The pain was worsened by loading of the leg going up and downstairs, and by single-leg exercises. She was treated with manual therapy, muscle activation, ice, and SAM® (4 hours/day, 6 days in 1 week). She reported mild pain relief with treatment with a reduction in pain severity.

\section{Knee}

Patellar Tendinosis. A 37-year old male amateur marathoner, who was new to the sport. He developed patellar tendonitis of his right knee and has had symptoms lasting 2-3 months. The pain was worsened by running and weight-bearing. Conservative treatment with RICE showed little effects. The addition of SAM® to RICE for 4 hours/day resulted in pain relief and functional improvement, enabling him to run and compete in the Boston Marathon.

Anterior Cruciate ligament tear: A 17-year old female basketball shooting guard with an anterior cruciate ligament (ACL) tear of her right knee underwent knee surgery. After surgery, RICE, and an ACL rehabilitation program, she did not have any change in the tendon symptoms. SAM ${ }^{\circledR}$ ( 4 hours/day) was then added to her treatment regimen for 2 weeks resulting in an improvement in pain and swelling, allowing her to continue to progress through the ACL rehabilitation program.

Osteochondral Fracture: A 24-year old male professional football player (right tackle) with a right medial osteochondral fracture. He was treated with microfracture surgery, RICE, soft tissue mobilization, and neuromuscular re-education yielding limited effectiveness on reduction of pain. Addition of SAM (4 hours/day for 4 weeks) the athlete reported reduced pain and tightness in the injured knee, allowing him to progress through rehabilitation effectively.

\section{Foot/Ankle}

A 19-year-old male amateur lacrosse player was treated with SAM ${ }^{\circledR}$ for bilateral distal posterior tibial tendinopathy. The athlete has been dealing with overuse injury for approximately 12 weeks and had not improved with conservative therapy (RICE). The addition of SAM $®$ for 4-hour daily treatments for 4 weeks applied to the ankles, in combination with RICE, soft tissue mobilization, and therapeutic exercise. The athlete reported improvements in pain and tightness with treatment. He experienced a reduction in pain and was able to return to lacrosse.

\section{Discussion}

The current study describes a case series of 18 athletes treated with $\mathrm{SAM}{ }^{\circledR}$ as adjunct therapy at a single sports medicine rehabilitation clinic. $S A M ®$ treatment resulted in reduced pain and improved function across numerous muscles, ligament, and tendon conditions. Most of the athletes examined were able to return to normal activity and function, including sports, during their treatment period. These athletes previously underwent surgeries or were being considered for surgery.

These studies used SAM $®$ (ZetrOZ System LLC) device with two transduces to deliver $\mathrm{SAM} \otimes$ at $3 \mathrm{MHz}$, at an intensity of $0.132 \mathrm{~W} /$ cm2 per transducer. Delivering 18720 Joules of energy over 4 hours of treatment. Multiple studies have shown the efficacy of SAM ${ }^{\circledR}$ device as an efficient technology to provide consistent $\mathrm{SAM} \AA$ over 4 hours $[28,38-41,43,45]$. Lewis et al. have demonstrated a constant acoustic signal and its effect on chronic myofascial pain, with a $25 \%$ reduction in the pain after 10 days of treatment and a $30 \%$ decrease in rotator cuff tendinopathy after 12 treatments $[43,46]$. Similarly, best et al. has shown $3.94(n=20, p<0.002)$ point decrease point reduction in elbow tendionopathathy $(\mathrm{n}=20)$ and $2.83 \mathrm{~kg}$ increase grip strength $(\mathrm{p}=0.02)$ after 6 weeks of treatment of SAM®[47]. SAM has also been shown to be effective for osteoarthritis.

Langer et al. showed a statistically significant $20 \%$ mobility in arthritic patients after 4 weeks of patients with $S A M \circledast[41]$. In a clinical study, Draper et al. determined the efficacy of SAM® with 90 arthritis patients. After 6 weeks of treatment, patients treated with active SAM ${ }^{\circledR}$ show 1.96 points $(\mathrm{p}<0.0001)$ decrease in the Numerical Rating Scale (NRS) of pain relative to 0.85 points in the placebo group. The Western Ontario McMaster Osteoarthritis Index (WOMAC) score also improved by 505 points in the active group relative to 311 points in the placebo group $(\mathrm{p}=0.02)$ [38].

The data for the effectiveness of ultrasound for inhibition of inflammation through inhibiting cytokines, recruiting stem cells to injury sites, increasing the rate of tissue regeneration through matrix formation via collagen alignment, and other matrix protein has been shown for decades in preclinical studies [48]. Still, the translation of ultrasound to clinical application has lagged [48]. One of the factors causing lagging of the ultrasound technology from preclinical to clinical application is the optimization of its parameters. The current studies with $\mathrm{SAM} \otimes$ provide us with encouraging data showing the effectiveness of ultrasound as in the clinical setting and its translation from preclinical to real-life clinical settings $[28,38,40,43,46,49,50]$. 
The clinical data in this study confirms the effectiveness of the application of therapeutic ultrasound in reducing pain as adjunct therapy or standalone therapy. Muffic et al have shown the effectiveness of different intensities of ultrasound in pain associated to degenerative musculoskeletal diseases [51]. Although, a recent study by Noor et al. failed to draw any conclusive recommendation about application ultrasound in treatment pain management due to heterogeneity of conditions such as duration, intensity, frequency, and mode of application [52]. Multiple meta-analyses show that low-intensity therapeutic ultrasound is beneficial for chronic pain $[35,53-55]$.

SAM ${ }^{\circledR}$ is an optimized low-intensity continuous therapy that accelerates the natural process of healing by inhibiting inflammation, increase the rate of tissue regeneration, angiogenesis, and nutrient exchange. The application of LICUS through SAM®, the portable device makes it easy for athletes to use it as an add-on device to active recovery regime and accelerate the rate of recovery and probability of returning to the sport.

\section{Conclusion/Summary}

Sport-related musculoskeletal injuries are highly prevalent and require novel approaches to accelerate healing. Traditional therapies may be insufficient for work-related injuries, causing athletes to suffer through pain and a long time to return to sporting activities. RICE, along with other therapies, has been used to treat musculoskeletal injuries. This study describes a case series of injured athletes receiving SAM $₫$ as an add-on therapy to traditional treatments to accelerate the healing process and decreases the pain and time to return to sporting activities as well as the overall quality of life.

\section{Acknowledgement}

None.

\section{Conflict of Interest}

Authors declare no conflict of interest.

\section{Disclosure}

Authors have nothing to disclose.

\section{References}

1. Aicale RD, Tarantino, N Maffulli (2018) Overuse injuries in sport: a comprehensive overview. J Orthop Surg Res 13(1): 309.

2. Fabricant PD, Nikita Lakomkin, Dai Sugimoto, Frances A Tepolt, Andrea Stracciolini, et al. (2016) Youth sports specialization and musculoskeletal injury: a systematic review of the literature. Phys Sportsmed 44(3): 257 262.

3. Humphrey JA, P Humphrey, AS Greenwood, JL Anderson, HS Markus, et al. (2019) Musculoskeletal injuries in real tennis. Open Access J Sports Med 10: 81-86.

4. Jancosko JJ, JE Kazanjian, (2012) Shoulder injuries in the throwing athlete. Phys Sportsmed 40(1): 84-90.

5. (2006) Centers for Disease, C and Prevention Sports-related injuries among high school athletes--United States, 2005-06 school year. MMWR Morb Mortal Wkly Rep 55(38): 1037-1040.
6. Patel DR, A Yamasaki, K Brown (2017) Epidemiology of sports-related musculoskeletal injuries in young athletes in United States. Transl Pediatr, 6(3): 160-166.

7. Weaver NL, SW Marshall, MD Miller (2002) Preventing sports injuries: opportunities for intervention in youth athletics. Patient Educ Couns 46(3): 199-204.

8. Hootman JM, R Dick, J Agel (2007) Epidemiology of collegiate injuries for 15 sports: summary and recommendations for injury prevention initiatives. J Athl Train 42(2): 311-319.

9. Eskstrand J, M Hagglund, M Walden (2011) Injury incidence and injury patterns in professional football: the UEFA injury study. Br J Sports Med 45(7): 553-538.

10. Ekstrand J, M Hagglund, M Walden (2011) Epidemiology of muscle injuries in professional football (soccer). Am J Sports Med 39(6): 12261232.

11. Kirkby Shaw K, Leilani Alvarez, Sasha A Foster, Julia E Tomlinson, Aaron J Shaw, et al. (2020) Fundamental principles of rehabilitation and musculoskeletal tissue healing. Vet Surg 49(1): 22-32.

12. Guillen Garcia P (2010) Cell and molecular medicine in musculoskeletal system lession (sports) (healing cells). An R Acad Nac Med (Madr) 127(1): 171-183.

13. Van den Bekerom MP, Peter A A Struijs, Leendert Blankevoort, Lieke Welling, C Niek van Dijk, et al. (2012) What is the evidence for rest, ice, compression, and elevation therapy in the treatment of ankle sprains in adults? J Athl Train 47(4): 435-443.

14. Jarvinen TA, Teppo L N Jarvinen, Minna Kaariainen, Ville Aarimaa, Samuli Vaittinen, et al. (2007) Muscle injuries: optimising recovery. Best Pract Res Clin Rheumatol 21(2): 317-331.

15. Gomes C, Almir Vieira Dibai-Filho, Fabiano Politti, Tabajara de Oliveira Gonzalez, Daniela Aparecida Biasotto-Gonzalez (2018) Combined Use of Diadynamic Currents and Manual Therapy on Myofascial Trigger Points in Patients with Shoulder Impingement Syndrome: A Randomized Controlled Trial. J Manipulative Physiol Ther 41(6): 475-482.

16. Johnston R, R Cahalan, MO Keeffe, KO Sullivan, T Comyns (2018) The associations between training load and baseline characteristics on musculoskeletal injury and pain in endurance sport populations: A systematic review. J Sci Med Sport 21(9): 910-918.

17. Tuakli-Wosornu YA, Evgeny Mashkovskiy, Taylor Ottesen, Mark Gentry, Daniel Jensenet, al. (2018) Acute and Chronic Musculoskeletal Injury in Para Sport: A Critical Review. Phys Med Rehabil lin N Am 29(2): 205-243.

18. Kannan P (2012) Management of myofascial pain of upper trapezius: a three-group comparison study. Glob J Health Sci 4(5): 46-52.

19. Owens BD, (2016) Return to Play Following Musculoskeletal Injury. Clin Sports Med, 35(4): 45-46.

20. Elkin JL, E Zamora, RA Gallo (2019) Combined Anterior Cruciate Ligament and Medial Collateral Ligament Knee Injuries: Anatomy, Diagnosis, Management Recommendations, and Return to Sport. Curr Rev Musculoskelet Med 12(2): 239-244.

21. Jiang X, Oleksandra Savchenko, Yufeng Li, Shiang Qi, Tianlin Yang, et al. (2019) A Review of Low-Intensity Pulsed Ultrasound for Therapeutic Applications. IEEE Trans Biomed Eng 66(10): 2704-2718.

22. Azuma Y, M Ito, Y Harada, H Takagi, T Ohta, et al. (2001) Low-intensity pulsed ultrasound accelerates rat femoral fracture healing by acting on the various cellular reactions in the fracture callus. J Bone Miner Res 16(4): 671-680.

23. Takikawa S, N Matsui, T Kokubu, M Tsunoda, H Fujioka, et al. (2001) Low-intensity pulsed ultrasound initiates bone healing in rat nonunion fracture model. J Ultrasound Med 20(3): 197-205.

24. Sahu N, HJ Viljoen, A Subramanian (2019) Continuous low-intensity ultrasound attenuates IL-6 and TNFalpha-induced catabolic effects and repairs chondral fissures in bovine osteochondral explants. BMC Musculoskelet Disord 20(1): 193. 
25. Da Silva Junior EM, Raquel Agnelli Mesquita-Ferrari, Cristiane Miranda Franca, Lucas Andreo, Sandra Kalil Bussadori, et al. (2017) Modulating effect of low intensity pulsed ultrasound on the phenotype of inflammatory cells. Biomed Pharmacother 96: 1147-1153.

26. Higgins A, Matthew Glover, Yaling Yang, Susan Bayliss, Catherine Meads, et al. (2014) EXOGEN ultrasound bone healing system for long bone fractures with non-union or delayed healing: a NICE medical technology guidance. Appl Health Econ Health Policy 12(5): 477-484.

27. Heckman JD, J P Ryaby, J McCabe, J J Frey, R F Kilcoyne (1994) Acceleration of tibial fracture-healing by non-invasive, low-intensity pulsed ultrasound. J Bone Joint Surg Am 76(1): 26-34.

28. Best TM, Kevin E Wilk, Claude T Moorman ， David 0 Draper (2016) Low Intensity Ultrasound for Promoting Soft Tissue Healing: A Systematic Review of the Literature and Medical Technology. Intern Med Rev (Wash D C) 2(11): 271

29. Lovric V, Michael Ledger, Jerome Goldberg, Wade Harper, Nicky Bertollo, et al. (2013) The effects of low-intensity pulsed ultrasound on tendonbone healing in a transosseous-equivalent sheep rotator cuff model. Knee Surg Sports Traumatol Arthrosc 21(2): 466-475.

30. Lu H, Ling Qin, Winghoi Cheung, Kwongman Lee, Wannar Wong, et al. (2008) Low-intensity pulsed ultrasound accelerated bone-tendon junction healing through regulation of vascular endothelial growth factor expression and cartilage formation. Ultrasound Med Biol 34(8): 1248-1260.

31. Walsh WR, Paul Stephens, Frank Vizesi, Warwick Bruce, James Huckle, et al. (2007) Effects of low-intensity pulsed ultrasound on tendon-bone healing in an intraarticular sheep knee model. Arthroscopy 23(2): 197204.

32. Chen WZ, Hai Qiao, Wei Zhou, Junru Wu, Zhi Biao Wang (2010) Upgraded nerve growth factor expression induced by low-intensity continuouswave ultrasound accelerates regeneration of neurotometicly injured sciatic nerve in rats. Ultrasound Med Biol 36(7): 1109-1117.

33. Song BW, Jun-Hee Park, Bomi Kim, Seahyoung Lee, Soyeon Lim, et al (2020) A Combinational Therapy of Articular Cartilage Defects: Rapid and Effective Regeneration by Using Low-Intensity Focused Ultrasound After Adipose Tissue-Derived Stem Cell Transplantation. Tissue Eng Regen Med 17(3): 313-322.

34. Wang Y, Zhaowu Chai, Yuanyuan Zhang, Feng Deng, Zhibiao Wang, et al. (2014) Influence of low-intensity pulsed ultrasound on osteogenic tissue regeneration in a periodontal injury model: X-ray image alterations assessed by micro-computed tomography. Ultrasonics 54(6): 15811584 .

35. Wu Y, Shibo Zhu, Zenghui Lv, Shunli Kan, Qiuli Wu, et al. (2019) Effects of therapeutic ultrasound for knee osteoarthritis: a systematic review and metaanalysis. Clin Rehabil 33(12): 1863-1875.

36. Daniels S, Gabriela Santiago, Jennifer Cuchna, Bonnie Van Lunen (2018) The Effects of Low-Intensity Therapeutic Ultrasound on Measurable Outcomes: A Critically Appraised Topic. J Sport Rehabil 27(4): 390-395.

37. Ilter L, Banu Dilek, Ibrahim Batmaz, Mehmet Ali Ulu, Mustafa A Sariyildiz et al. (2015) Efficacy of Pulsed and Continuous Therapeutic Ultrasound in Myofascial Pain Syndrome: A Randomized Controlled Study. Am J Phys Med Rehabil 94(7): 547-554.

38. Draper DO, Dominic Klyve, Ralph Ortiz, Thomas M Best (2018) Effect of low-intensity long-duration ultrasound on the symptomatic relief of knee osteoarthritis: a randomized, placebo-controlled double-blind study. J Orthop Surg Res 13(1): 257.

39. Petterson S (2020) Low-Intensity Continuous Ultrasound for the Symptomatic Treatment of Upper Shoulder and Neck Pain: A Randomized, Double-Blind Placebo-Controlled Clinical Trial. Journal of Pain Research 13: 1899-1900.
40. Rigby JH, Rebecca M Taggart, Kelly L Stratton, George K Lewis, David 0 Draper (2015) Intramuscular Heating Characteristics of Multihour LowIntensity Therapeutic Ultrasound. J Athl Train 50(11): 1158-1164.

41. Langer MD, Vanessa Levine, Rebecca Taggart, George K Lewis, Lyndon Hernandez, et al. (2014) Pilot Clinical Studies of Long Duration, Low Intensity Therapeutic Ultrasound for Osteoarthritis. Proc IEEE Annu Northeast Bioeng Conf

42. Langer MD, GK Lewis (2015) Sustained Acoustic Medicine: A Novel Long Duration Approach to Biomodulation Utilizing Low Intensity Therapeutic Ultrasound. Proc SPIE Int Soc Opt Eng 9467.

43. Lewis GK, Matthew D Langer, Charles R Henderson, Ralph Ortiz (2013) Design and evaluation of a wearable self-applied therapeutic ultrasound device for chronic myofascial pain. Ultrasound Med Biol 39(8): 14291439.

44. World Medical A, (2013) World Medical Association Declaration of Helsinki: ethical principles for medical research involving human subjects. JAMA 310(20): 2191-2194.

45. D Langer M, BH Henry T (2017) The Effect of Low Intensity Wearable Ultrasound on Blood Lactate and Muscle Performance after High Intensity Resistance Exercise. J Exerc Physiol, 20: 14.

46. Lewis G HL, Lewis Sr GK Ortiz (2013) Wearable long duration ultrasound therapy pilot study in rotator cuff tendinopathy. Proc Meet Acoust 19.

47. Best TM, Bob Moore, Paddy Jarit, Claude T Moorman, George K Lewis (2015) Sustained acoustic medicine: wearable, long duration ultrasonic therapy for the treatment of tendinopathy. Phys Sportsmed 43(4): 366374.

48. Uddin SMZ, DE Komatsu (2020) Therapeutic Potential Low-Intensity Pulsed Ultrasound for Osteoarthritis: Pre-clinical and Clinical Perspectives. Ultrasound Med Biol 46(4): 909-920.

49. Draper DO, JC Castel, D Castel (1995) Rate of temperature increase in human muscle during $1 \mathrm{MHz}$ and $3 \mathrm{MHz}$ continuous ultrasound. J Orthop Sports Phys Ther 22(4): 142-150.

50. Stratton K, Rebecca Taggart, George K Lewis (2014) Long duration ultrasound facilitates delivery of a therapeutic agent. Journal of the Acoustical Society of America 4(136): 1.

51. Muftic M, K Miladinovic, Therapeutic ultrasound and pain in degenerative diseases of musculoskeletal system. Acta Inform Med, 21(3): 170-172.

52. Noori SA, Abdullah Rasheed, Rohit Aiyer, Boyoun Jung, Nitin Bansal, et al. (2019) Therapeutic Ultrasound for Pain Management in Chronic Low Back Pain and Chronic Neck Pain: A Systematic Review. Pain Med 21(7): 1482-1493.

53. Loyola-Sanchez A, J Richardson, NJ MacIntyre (2010) Efficacy of ultrasound therapy for the management of knee osteoarthritis: a systematic review with meta-analysis. Osteoarthritis Cartilage 18(9): $1117-1126$

54. Park SR, Sang-Hyug Park, Kyung Wha Jang, Hong Sik Cho, Ji Hao Cui, et al. (2005) The effect of sonication on simulated osteoarthritis. Part II: alleviation of osteoarthritis pathogenesis by $1 \mathrm{MHz}$ ultrasound with simultaneous hyaluronate injection. Ultrasound Med Biol, 31(11): 15591566.

55.Zhang C, Yujie Xie, Xiaotian Luo, Qiaodan Ji, Chunlan Lu, et al. (2016) Effects of therapeutic ultrasound on pain, physical functions and safety outcomes in patients with knee osteoarthritis: a systematic review and meta-analysis. Clin Rehabil 30(10): 960-971. 